\title{
Review
}

\section{Göç Araştırmalarına Eleştirel Bakışlar: Dünden Bugüne Göç Araştırmaları}

Kübra Hıdıroğlu Alarçin ${ }^{a}$

Critical Reflections in Migration Research: Views from the North and the South Edited by Ahmet iç̧uygu-Ayşem Biriz Karaçay

Istanbul, 2015, Koç University Press, 178 pages

Göç, insanlık tarihi kadar eski bir olgudur. Uluslararası göç hareketleri, dünyada ekonomik, siyasi ve kültürel şartların değişmeye başladığı 19. yüzyıl ile tarihlendirilebilir. Ancak göç üzerine yapılan araştırmaların bu tarihlerden yaklaşık yüzyıl sonra 20. yüzyılın ortalarından itibaren ivme kazandığını söylemek mümkündür. Araştırmalar başlarda politik sebepler dolayısıyla devletlerin kontrolü altında yürütüldüğü için yeterli derecede açık ve objektif değildir. Ancak araştırmaların bu özelliklerinin zamanla hem perspektif hem de yöntem açısından daha olumlu yönde değişiklik gösterdiğini söylemek mümkündür. Özellikle pek çok araştırmanın (ki bugün hâlâ belli oranlarda geçerliliğini koruyarak) "gelişmiş” Batı perspektifinden dile getirildiğini görmek mümkündür.

Bununla beraber göç araştırmalarında dünyanın ekonomik, siyasi ve kültürel değişimine bağlı olarak her dönem farklı grupların -örneğin Sanayi Devrimi sonrası işçi göçleri- "popüler" hâle geldiği görülmektedir. Bu durum, her ne kadar şartların değişimine paralel olarak olağan bir yönelim gibi görünse de "dünyanın hangi yöne döndüğü" ile yakından ilgilidir. Bu noktada temel sorular şu şekilde formülleştirilebilir: Uluslararası göç meselesi bakımından "dünyanın hangi yöne döndüğünü” belirleyen nedir? 20. yüzyıldan itibaren göç tiplerindeki ve dolayısıyla göç araştırmalarındaki değişiklikler nasıl açıklanabilir? Kuzey ve güney yarımküre arasında göç araştırmaları, kavramları ve perspektifleri açısından hangi değişiklikler göze çarpar? 
Koç Üniversitesi Göç Araştırmaları Uygulama ve Araştırma Merkezi (MíREKOÇ) Müdürü Prof. Dr. Ahmet İçduygu ve MíREKOÇ Araştırmacısı Dr. Ayşem Biriz Karaçay tarafindan derlenen, 12 makaleden oluşan "Critical Reflections in Migration Research-Views from the North and the South" adlı eserde, Dünya'nın kuzey ve güneyindeki göçlerle ilgili farklı perspektiflerden derlenmiş makaleler ile genel olarak göç araştırmalarının dünü, bugünü ve muhtemel yarını değerlendirilmekte, mevcut eksiklikler ve bu eksikliklerin nasıl giderileceği, sorulması gereken soruların neler olduğu ele alınmaktadır. 2015 yılında Koç University Publishing tarafından basılan eserde bütünü itibarı ile göç araştırmaları ele alınırken farklı makaleler ile de ülkelerin göç araştırmaları açısından değişen perspektifleri değerlendirilmektedir. $\mathrm{Bu}$ açıdan bir göç araştırmaları analizi sunan eserde, uluslararası göç hakkında temel noktalar hatırlatılarak eski ve yeni araştırmalar arasında amaç ve yöntem açısından köprü kurarak birçok açıdan karşılaştırmalı bir perspektif sunmak amaçlanmıştır.

İlk makale (Migration Research from the West: Shortcomings and Challenges, s. 1934) Rinus Penninx'in çalışması olup makalede Batı' daki göç araştırmalarının eksiklikleri ve zorlukları ele alınmaktadır. Bu anlamda uluslararası göç alanında Avrupa'da ne gibi değişikliklerin olduğuna, Avrupa toplumlarının ve araştırma çevresinin bu değişimlere nasıl tepki gösterdiğine odaklanılmaktadır. Penninx, Avrupa'daki araştırma eksikliklerin nedenlerine ve nasıl çare bulunabileceğine değinirken bunun pratikte hangi sonuçlara yol açabileceğini de ortaya koymaktadır.

Sema Erder ve Deniz Yükseker tarafindan kaleme alınan ikinci makale (Challenges for Migration Research in Turkey: Moving Beyond Political, Theoretical and Data Constuctions, s. 35-56) Türkiye'de uluslararası göç çalışmalarının eleştirel bir değerlendirmesini ve bu değerlendirmeye dayanarak gelecekte yapılacak olan çalışmalara yeni perspektif önerileri sunmaktadır. Ayrıca Erder ve Yükseker bu makalede Türkiye'de araştırmaların ne gibi zorluklarla yürütüldüğüne, hangi alanlarda eksiklikler bulunduğuna ve yeni araştırmaların hangi sorularla yola çıkması gerektiğine dair bir tartışma ortaya koymaktadır.

İzabela Grabowska-Lusinska'ya ait makale ise (New Directions in Migration Research in Poland in Light of Theoretical and Methodological Paradigms, s. 57-71) Polonya'daki göç araştırmalarının yeni yönelimlerini ele almaktadır. Lusinska'nın, Polonya'daki göç araştırmalarını özellikle uygulanan yeni yaklaşımlar ışığında tartıştığı makalede, bu araştırmaların Batı Avrupa araştırmalarına yakın ve uzak olduğu noktalar ele alınmıştır. Özellikle komünizmin çöküşünden önce ve sonra araştırmaların hangi yöne evrildiği üzerine odaklanan makalede uygulanan farklı yaklaşımlar da ele alınarak Polonya'da göç araştırmalarının yeni yönelimleri incelenmiştir.

Kitaptaki bir diğer çalışma olan Can M. Aybek'in, Alman göç ve uyum politikalarındaki son gelişmeleri ele aldığı makalesi (Recent Develoments in German İmmig- 
ration and Integration Policy-Making, s. 75-90) 1955-1989, 1990-1998, 1998-2005 yılları olarak ele aldığı üç ayrı dönem üzerinden Batı Almanya'da savaş sonrası göç politikaları ve misafir işçiler döneminden mevcut yasal çerçeveye uzanan bir sürecin analizini sunmaktadır. Aybek, yüzyılın başından itibaren uygulanan yeni göç kanunu ile Almanya'da göç ve göç araştırmaları alanında nelerin değiştiğini ele almaktadır.

Yine özel olarak Fas ve Fransa arasındaki göçü inceleyen Anna Vırkama'nın makalesinde (Migration Between Morocco and France, s. 91-101) iki ülke arasındaki göçün tarihi ele alınmıştır. Fransa' daki Faslı göçmenler üzerine araştırmalara odaklanan Vırkama, Faslı göçmenlerin entegrasyon süreçlerini incelemekte...

Polonyalıların, Birleşik Krallık'a göçünü ele alan makalede (Polish Migration to the UK, s. 103-122), Franck Düvell ve Michal Garapich'in detaylı çalışması ile bu göçün tarihi ele alınmakla birlikte Polonya'nın Avrupa Birliğine katılmadan önceki ve sonraki durumu dikkate alınarak detaylı bir çalışma oluşturulmuştur. Polonyalıların, Birleşik Krallık'a göçünü 1800'lere kadar geri götüren Düvell ve Garapich, göçü jeopolitik bir perspektiften ele almakta ve göçün göçmenler tarafından nasıl algılandığını, göçün bireysel ve sosyal sonuçlarını da irdelemektedir.

$\mathrm{Bu}$ çalışmanın devamı niteliğinde sayılabilecek bir diğer makale (The State of Research on International Migration in Poland, s. 125-145) Marek Okolski'nin Polonya'da uluslararası göç araştırmalarının durumunu yansıtan makalesidir. Okolski, 19. yüzyılın sonundan itibaren büyük çapta bir göç ülkesi olan Polonya'da uluslararası göçün sürekli güncel bir mesele olduğunu belirtir. Metodoloji çalışmalarına da değinen makalede aynı zamanda hem dışa göç hem de içe göç hakkındaki araştırmalar da incelenmiştir.

Türkiye'deki göç çalışmalarına odaklanan makalesinde (The State of the Art in Migration Research in Turkey, s. 147-153) Kemal Kirişçi göç çalışmalarının, literatürün ve Türkiye'deki göç yönetimini destekleyen kuruluşların durumunu ele almaktadır. Türkiye'de son yıllarda göç hakkında yapılan çalışma ve bu çalışmaları destekleyen ya da yürüten kuruluşların arttı̆̆ görülmektedir. Bu konuda Koç Üniversitesi Göç Araştırmaları Merkezi (MİREKOÇ), Hacettepe Üniversitesi Göç ve Siyaset Araştırmaları Merkezi (HUGO), Bilgi Üniversitesi Göç Çalışmaları Uygulama ve Araştırma Merkezi, Gazi Üniversitesi Göç ve Nüfus Araştırmaları Uygulama ve Araştırma Merkezi gibi örnekler artan ilgiye verilebilecek örneklerden yalnızca birkaçıdır.

Noureddine Harrami'nin kaleme aldığı makale (New Directions in Migration Research in Morocco, s. 155-160) Fas'taki göç araştırmalarının yeni yönelimleri üzerine odaklanmaktadır. Fas'tan göçün tarihine değinen Harrami, göç modelleri araştırmas1nı iki döneme ayırır. Göçün ekonomik bir gelişme için temel faktör olduğunu belirten Harrami’ye göre göç aynı zamanda sosyal hayatı da etkiler. Bu zaten kaçınılmaz bir etkidir. Burada ise akla gelen göçün sosyal hayatta kimliği nasıl etkilediği ve göçmenlerin kimliklerini nasıl değiştirdiğidir. 
Pırkko Pıtkanen'in yeni göç araştırmaları ve uluslararası işbirliği için bir çağrı niteliğinde olan makalesinde (A Call for New Questions and More International Cooperation to Enhance Research an Migration, s. 161-163) P1tkanen, bugün dünyanın farklı bölgelerinde tahminen 214 milyon göçmen bulunduğunu ifade ediyor ve tek bir disiplinin bu uluslararası göçün tüm bileşenlerini açıklayamayacağını belirtiyor. $\mathrm{Bu}$ tespit ve dolayısıyla çağrı araştırmacıların daha bütünsel bir anlayışa geçmeleri gerektiği üzerine bir öneri olarak da okunmalıdır. Pıtkanen'e göre araştırmalarda asıl amaç, yalnızca ulusal değil aynı zamanda uluslararası düzeyde de göçmen toplulukları ve göç alan toplulukları etkileyen göç yollarını anlamak olmalıdır.

Jobst Koehler'in göç araştırmalarının altyapısını hükûmetler arası bir perspektifle ele aldığı makalesinde (Migration Research Infrastructure: An Inter-Governmental View, s. 165-168), Koehler makalenin amacını araştırma işbirliğini ve araştırma altyapısı kurmayı desteklemek olarak belirtmiştir. Günümüzde her ne kadar uluslararası araştırma işbirlikleri artıyor olsa bile, ne yazık ki hâlâ gereken sayıda uluslararası araştırma yapılamadığını söylemek mümkündür. Hem maddi yetersizlikler, fon bulma sorunları hem de özellikle göç araştırmalarında politik yönelimlerin araştırmalarda ortaya çıkıyor oluşu araştırmaları olumsuz yönde etkilemektedir.

Kitabın son makalesi (Practical Issues in Migration Research: A View from Europe's Periphery) Marek Kupiszewski'ye aittir. Göç araştırmalarında uygulamalı meselelerin Orta Avrupa ve Avrupa çevresinden farklı bakış açılarıyla ele alındığı makale, aslında bu iki çevrenin deneyimleri açısından ne kadar farklı olduğunu ortaya koymaktadır. Demografinin uluslararası göç çalışmaları için önemini de ortaya koyan Kupizewski, Orta ve Doğu Avrupa'da ne yazık ki yeterince kurumsallaşamamış bir demografi ile karşı karşıya olunduğunu belirtmektedir. Ayrıca göç araştırmalarında sıkça karşılaşılan fon bulma sorunu Kupiszewski'ye göre bilimsel incelemenin kalitesi açısından bazı olumsuz sonuçlara yol açmaktadır.

Sonuç olarak, bu kitapta da genel olarak tartışıldığ üzere, göç araştırmaları dünden bugüne görülebilir düzeyde gelişme gösterse de bugün hâlâ bazı sorunlar araştırmacıları zorlamaktadır. Bu açmazların neler olduğu, araştırmaların nereden nereye ulaştığı ve bundan sonrası için neler yapılabileceği üzerine ipuçları veren eser, sorulara cevap vermekten öte öncelikle biraz da soru sormaya teşvik etmesi bakımından alandaki yeni araştırmacılar için perspektifler geliştirebilir. Ancak yine de bu alanda uluslararası literatürü sıkı takip eden bir okuyucunun beklentilerini gidermesi açısından, her çalışmada görülebilecek zayıf noktalarla karşılaşabilir. Fakat bu durum eserin Türkiye'deki çalışmalar açısından bir boşluğu doldurduğu gerçeğini gözden kaçırmaya sebep olmamalıdır. Bu tür çalışmalar özellikle göç çalışmaları üzerine yoğunlaşan akademik çevreye yeni bakış açıları kazandırmaktadır. Yine de bu anlamda eserin dilinin İngilizce olması, hitap ettiği çevreyi de kısıtlayabilecek bir diğer faktör olarak göz önünde bulundurulmalıdır. 